\title{
EFFECT OF HONEY BEE (APIS MELLIFERA L.) DENSITY ON POLLINATION AND FRUIT SET OF AVOCADO (PERSEA AMERICANA
}

MILL.) CV. HASS.

\author{
Juan F. Peña ${ }^{1 *}$ \\ Arturo Carabalí \\ ${ }^{1}$ National University of Colombia, Palmira, Colombia \\ 2Colombian Corporation for Agricultural Research (CORPOICA), Palmira Research \\ Center, Palmira, Colombia \\ *corresponding author: jpenam@unal.edu.co \\ Received: 05April 2017; accepted: 08 January 2018
}

Abstract

The objective of this research was to determine the effect of honeybee density on pollination and fruit set of the Hass avocado. The research was carried out in the municipality of Popayán, Colombia. Three avocado orchards were selected, each one with an area of one hectare and trees with an age of six years. The treatments were: 1) four hives/ ha, 2) six hives/ha, and 3) control without hives. Treatments of six and four hives/ha presented significant differences with respect to the control, with a honeybee density per tree of 7.72, 6.04 and 2.72 , pollination rate of 60,55 and $50 \%$, pollination efficiency of 7.57, 6.04 and 5.98 grains of pollen per stigma, $6.11,4.13$ and $3.54 \%$ fruit set initial, $0.058,0.048$ and $0.028 \%$ fruit set final, 231,212 and 137 of fruits per tree, $46.2,38.2$ and $21.6 \mathrm{~kg}$ fruit per tree, respectively. The results obtained show an increase of honeybee density per tree, pollination rate, pollination efficiency, \% fruit set, \% fruit set final, number of fruits per tree and total fruit weight per tree when six and four bee hives/ha are introduced in the avocado crop.

Keywords: Apis mellifera, avocado, honeybee, pollination efficiency, pollination rate

\section{INTRODUCTION}

Pollination is a key process for both ecosystems and agroecosystems, whose efficiency is directly affected by the richness of pollinators (Cepeda, Gómez, \& Nicholls, 2014). At the global level, $75 \%$ of primary crop species and $35 \%$ of crop production rely on some level of animal pollination (Klein et al., 2007). Economically, the value of insect pollination services to crop agriculture has been estimated at $€ 153$ billion per annum globally (Gallai et al., 2009). In recent years, decreases in pollinator populations have been reported (Dewenter et al., 2005; Geslin et al., 2016). Decreased abundance and diversity of such pollinators as wild bees, hoverflies and butterflies at local and regional levels have been documented, (Potts et al., 2005; Aizen \& Harder 2009; Biesmeijer et al., 2006; Carvalheiro et al., 2013). Furthermore, a significant decrease has been reported in the number of honey bee colonies on a regional scale in Europe and North
America. These reductions of bee populations are mainly due to the loss and homogenization of habitats, pesticides, parasites and pathogens, invasive species and climate change (Potts et al., 2005; Brown et al., 2016).

It is estimated that 73\% of crops are pollinated by bees (Zych \& Jakubiec, 2006). They are probably the group of insects best adapted to the floral visit, which is why they have become an essential group for pollination and therefore for the sexual reproduction of most flowering plants, including many of agricultural interest (Michener, 2000; Рarra, 2005). In addition, the honey bee (Apis melliferaL.) is the most versatile, ubiquitous, and commonly used managed pollinator (Free, 1970; Klein et al., 2007).

Inadequate pollination has been suggested as an important factor in the limiting of the avocado (Persea americana Mill.) yield. This species presents the phenomenon of dichogamy proterogyny synchrony, i.e. sequential development of reproductive functions. Avocado cultivars are 
classified into complementary flowering groups $A$ and $B$, based o their daily flowering pattern. The type $A$ flowers open in the female form in the morning and close in the afternoon but then open again in the masculine form in the afternoon of the following day. The type $B$ flowers open in the female form in the afternoon; they then close and reopen the following morning in the male form (Sedgley, 1979; Ish-Am, 2004). The adoption of dichogamy as a breeding strategy implies that for an effective transfer of pollen, insects should visit the flowers in both sexual states. Fruit set is minimal or absent when insect pollinators such as bees and flies are excluded through caging (Malerbo-Souza et al., 2000).

Pollen-carrying vectors play a key role in the pollination and increase in the genetic variability of avocados because a considerable number of fruits are produced only through cross pollination (Bergh, 1977; Gazit \& Degani, 2002). Avocado flowers are visited by a variety of insects including bees, flies, wasps, beetles and thrips (Vithanage, 1990). In Central America the avocado is pollinated by stingless bees (Meliponinae) and wasps (Vespidae) (Ish-Am \& Eisikowitch, 1993), in Colombia Vásquez et al. (2011) established that ants, bees ( $A$. mellifera and trigone), flies and wasps are the most frequent floral visitors.

The honey bee $A$. mellifera is considered the main pollinating agent of the avocado (Free, 1970; Nieto, 1984; Davenport, 1986; Ish-Am \& Eisikowitch, 1993; Avilán \& Rodríguez, 1995; Castañeda et al., 1999; Peña, 2003; Can-Alonso et al., 2005; Goodwin, 2012). However, despite this and in comparison with other fruit trees, bees do not work efficiently in avocado flowers as they get more attracted by flowers of wild plants grown in orchards (Ish-Am \& Eisikowitch, 1993). Fur thermore, it has even been suggested that bees do not frequently visit avocado flowers due to repellent properties and high concentrations of minerals and perseitol alcohol in their nectar (Afik et al., 2006; Pérez-Balam et al., 2012; Afik et al., 2014).

An avocado tree produces about one million flowers and 10000 to 40000 female flowers open each day in Israel (Lahav \& Zamet, 1999).
A good seasonal crop of 400 to 600 fruits per tree requires the pollination and fertilization of about the same number of flowers, which may be accomplished with only two or three forager honey bees. However, in practice a measurable initial fruit set under field condition demands the work of at least five to ten honey bees per tree throughout the female bloom (Ish-Am, 2004).

In avocado orchards, it is common practice to introduce colonies of bees to promote pollination (Pérez-Balam et al., 2012). In New Zealand, four to ten hives/ha is recommended (Evans, Goodwin, \& Mcbrydie, 2010), while in Israel, it the optimal number of hives/ha has been found to be eight, placed at distances not less than $100 \mathrm{~m}$ between them (Bergh, 1977). Goodwin (2012) recommended the introduction of hives when the crop presented between 5 and $10 \%$ of flowering, guaranteeing its persistence in the flowers.

Bee-pollinator number density is the most important of the several factors that contribute and change to increase productivity. Research has shown that pollination by honey bee increases the fruit set in avocados (Ish-Am \& Eisikowitch, 1993; Goodwin, 2012). Even though measuring pollinator performance is difficult, it assesses pollinator behavior and estimates stigmatic pollen deposition (Freitas \& Paxton, 1998; Ne'eman et al., 2010; Pérez-Balam et al., 2012). This study deals with honey bee visitation activity per tree evaluated per unit time, quantity of pollen deposited on the stigma, initial and final fruit set, and the weight and number of fruits per tree. Considering the limitations of pollination in avocado, the objective of this research was to determine the effect of honey bee density on pollination and fruit set of avocado cv. Hass.

\section{MATERIAL AND METHODS}

\section{Field trial}

The research was conducted in the municipality of Popayán, department of Cauca, Colombia, during 2015 in three avocado orchards (Persea americana Mill.) Cv. Hass with an area of one hectare for each. The trees had a distance 
of $6 \times 6 \mathrm{~m}$ between one another, an average height of four meters and age of six years old. The first orchard was located geographically at $02^{\circ} 27^{\prime} 44.0^{\prime \prime} \mathrm{N}, 76^{\circ} 34^{\prime} 03.8^{\prime \prime} \mathrm{W}$, the second orchard $02^{\circ} 27^{\prime} 17.1^{\prime \prime} \mathrm{N}, 76^{\circ} 34^{\prime} 05.5^{\prime \prime} \mathrm{W}$ and the third orchard $02^{\circ} 27^{\prime} 32.4^{\prime \prime} \mathrm{N}, 76^{\circ} 34^{\prime} 03.7^{\prime \prime} \mathrm{W}$, and all were separated by a distance of one $\mathrm{km}$. The average annual precipitation in the research area was 1941 mm, a mean annual temperature of $19^{\circ} \mathrm{C}$ and altitude of $1735 \mathrm{~m}$ above sea level. Around the orchards there were large intensive monocultures systems planted with eucalyptus (Eucalyptus grandis W. Hill ex Maiden.) and pine (Pinus tecunumanii Eguiluz \& J.P. Perry.), as well as small avocado orchards.

The treatments were 1) four hives/ha, 2) six hives/ha and 3) control without hives. The honey bee hives ( $A$. m. scutellata) used were of the Langstroth type and located in the center of each orchard. Within each orchard five sites were selected, covering a range of distance to the hives: 50, 100, 150, 200 and $250 \mathrm{~m}$. At each site four trees were sampled, with a total of 20 trees per orchard. These sites were selected to quantify the effect of the distances from the hives to the selected trees.

\section{Density of bees per tree (BPT)}

The BPT was recorded during the flowering period of the second half of 2015; between 1 and 30 of September, the average temperature for this period was $20.3^{\circ} \mathrm{C}$ and relative humidity on average $68.7 \%$. The BPT was quantified by a person walking around a tree and counting with a manual counter the presence of the bees per minute (Free \& Spencer, 1963; Mayer, Johansen, \& Burgett, 1986; Ish-Am \& Eisikowitch, 1998; Ish-Am \& Lahav, 2011). The BPT was documented on every observation day in each treatment, and recorded every hour from 8.00 to 16.00 . Four recordings (one per week) were performed per treatment during the flowering phase in one tree for each distance.

Pollination rate and efficiency (PR and PE)

A sample of stigmas per tree was collected in the female flowering stage, three hours after the opening of the flower in the female phase, between 12.00 and 14.00, which was the time lapse overlap of the female and male phases.
The average temperature for this period was $21.3^{\circ} \mathrm{C}$ and relative humidity on average $67 \%$. The stigmas were collected with a clamp and placed on a microscope slide covered with $2 \%$ $(w / v)$ gel of carboxymethyl cellulose [in a ratio of 1:2:7 (v/v/v) ethanol: glycerol mixture: water, with the addition of aniline blue, to create a light blue solution] and the number of pollen grains per stigma was recorded under a microscope optical (Ish-Am \& Eisikowitch, 1991a; Ish-Am \& Eisikowitch, 1991b; Ish-Am \& Lahav, 2011). A total of 600 stigmas samples were collected, 200 per treatment, 40 stigmas per tree, 4 recordings per treatment (one per week) during the female flowering phase. The pollination rate (percentage of stigmas pollinated $\backslash$ total stigmas collected) and pollination efficiency (average number of pollen grains in the stigma, only for pollinated stigmas) was quantified for each treatment.

\section{Percentage of fruit set initial (PFSi)}

In order to determine the PFSi, the number of flowers (flowering) and the number of fruits (four weeks after the end of flowering) were recorded on five inflorescences per randomly selected tree, in twenty trees per treatment. The PFSi was calculated as follows: PFSi= Number of fruits set / Number of flowers * 100.

\section{Percentage of fruit set final (PFSf)}

In order to determine the PFSf, the number of flowers (flowering) and the number of final formed fruits (40 weeks after the end of flowering) were recorded on five inflorescences per randomly selected tree, in twenty trees per treatment. To determine the PSFf, the following equation was used: PSFf $=$ Number of fruits formed / Number of flowers * 100.

Weight and total number of fruits per tree (WFTT and NFTT)

The WFTT and NFTT were recorded 40 weeks after the end of flowering and all the fruits of each tree (20 trees per treatment) were harvested, counted and weighed.

\section{Statistical design}

For the statistical analysis a split-plot design was applied. Treatments with different densities of honey bee hives (four, six hives/ha and control without hives) constituted the main 
plot. The distances from the apiary to the trees selected as the sampling unit (50, 100, 150, 200 and $250 \mathrm{~m}$ ) constituted the sub-plots, for each sowing distance, four trees were evaluated for the variables number of bees per tree, pollination rate, pollination efficiency, $\%$ of fruit set initial, $\%$ of fruit set final, number of total fruits per tree and total fruit weight per tree. A generalized linear model was applied. The Duncan test was used for the comparison of means for each factor. Subsequently, a Pearson correlation analysis was performed on the evaluated variables. All statistical analyzes were carried out using the $\mathrm{SAS}^{\circledR}$ statistical package (Statistical Analysis System Version 9.4).

\section{RESULTS}

\section{Number of bees per tree (BPT)}

The BPT differed significantly among the treatments, the orchard with six and four hives/ ha had a higher BPT in comparison to the control (Tab. 1). By introducing six and four hives/ha, BPT increased by 4.93 and 3.26, respectively, compared to an orchard without hives. The BPT were much higher in distances of 50, 100 and $150 \mathrm{~m}$ compared to distances of 200 and 250 $\mathrm{m}$ (Tab. 2). The BPT was much higher at 14.00, $13.00,12.00$ and 11.00 with means of $7.46,6.23$, 5.76 and 5.83, respectively, compared with recordings at $10.00,9.00,8.00,15.00$ and 16.00 with means 5.35, 4.93, 4.60, 5.26 and 4.20, respectively.

\section{Pollination rate (PR)}

The PR differed significantly between treatments with a higher PR in the treatment of six hives/ha, compared to the treatment of four hives/ha and the control (Tab. 1). By introducing six and four hives/ha, PR increased by 12 and $4 \%$, respectively, compared to an orchard without hives. The PR was not significantly different in the evaluated distances $(50,100$, 150, 200 and $250 \mathrm{~m}$ ) (Tab. 2).

\section{Pollination efficiency (PE)}

The PE differed significantly between treatments, presenting a higher PE in treatments of six and four hives/ha compared to the control (Tab. 1). By introducing six and four hives/ha, PE increased by 2.29 and 1.32 pollen grains in the stigma, respectively, compared to an orchard without hives. The PE differed significantly between treatments at the evaluated distances (50, 100, 150, 200 and $250 \mathrm{~m})$, being higher at distances of 50 and 100 compared with distances of 150, 200 and $250 \mathrm{~m}$ (Tab. 2).

\section{Percentage of fruit set initial (PFSi)}

The PFSi differed significantly between treatments, with a higher PFSi in the treatment of six hives/ha compared to the treatment of four hives/ha and the control (Tab. 1). By introducing six and four hives/ha, the PFS increased by 2.57 and $0.59 \%$, respectively. The PFSi differed significantly between treatments at the evaluated distances (50, 100, 150, 200 and $250 \mathrm{~m})$. The highest PFSi was present at distances of 50 and 100 m compared with distances of 150, 200 and $250 \mathrm{~m}$ (Tab. 2).

\section{Percentage of fruit set final (PFSf)}

The PFSf differed significantly between treatments, being in the treatment of six hives/ ha compared to the treatment of four hives/ha and the control (Tab. 1). By introducing six and four hives/ha, the PFSf increased by 0.03 and $0.02 \%$, respectively, compared to an orchard without hives. The PFSf did not significantly differ at the distances evaluated $(50,100,150$, 200 and $250 \mathrm{~m}$ ) (Tab. 2).

\section{Number of total fruits per tree (NFTT)}

The NFTT differed significantly between treatments, higher in treatments of six and four hives/ha compared to the control treatment (Tab. 1). By introducing six and four hives/ha, the NFTT increased by 93.4 and 74.4 fruits per tree, respectively, compared to an orchard without hives. The NFTT did not significantly differ at the distances evaluated $(50,100,150,200$ and $250 \mathrm{~m}$ ) (Tab. 2).

\section{Total fruit weight per tree (WFTT)}

The WFTT differed significantly between treatments, higher in treatments of six and four hives/ha compared to the control treatment (Tab. 1). The WFTT increased by 26.4 and $17.5 \mathrm{Kg}$, respectively, compared to an orchard without hives. The WFTT did not significantly differ at the distances evaluated $(50,100,150$, 200 and $250 \mathrm{~m}$ ) (Tab. 2). 
Table 1.

Averages and significance of differences between the treatments number of hives

\begin{tabular}{ccccc}
\hline \multirow{2}{*}{ Variables } & \multicolumn{3}{c}{ Number of hives/ha } & GLM \\
\cline { 2 - 5 } & $\mathbf{0}$ & $\mathbf{4}$ & $\mathbf{6}$ & $\operatorname{Pr}>\mathbf{F}$ \\
\hline Density of bees per tree (BPT) & $2.78 \mathrm{c}$ & $6.04 \mathrm{~b}$ & $7.72 \mathrm{a}$ & $<.0001$ \\
Pollination rate (PR) & $50.0 \mathrm{~b}$ & $55.5 \mathrm{~b}$ & $66.5 \mathrm{a}$ & 0.004 \\
Pollination efficiency (PE) & $5.98 \mathrm{c}$ & $7.34 \mathrm{~b}$ & $8.27 \mathrm{a}$ & $<.0001$ \\
Percentage of fruit set initial (PFSi) & $3.54 \mathrm{~b}$ & $4.13 \mathrm{~b}$ & $6.11 \mathrm{a}$ & 0.0004 \\
Percentage of fruit set final (PFSf) & $0.028 \mathrm{~b}$ & $0.048 \mathrm{ab}$ & $0.058 \mathrm{a}$ & 0.0159 \\
Total number of fruits per tree (NFTT) & $137.9 \mathrm{~b}$ & $212.3 \mathrm{a}$ & $231.3 \mathrm{a}$ & $<.0001$ \\
Weight of fruits per tree (WFTT) & $21.6 \mathrm{c}$ & $38.2 \mathrm{~b}$ & $46.2 \mathrm{a}$ & $<.0001$ \\
\hline
\end{tabular}

* Mean with the same letter in the rows are not significantly different.

Table 2.

Averages and significance of differences between the treatments' distance to apiary

\begin{tabular}{ccccccc}
\hline \multirow{2}{*}{ Variables } & \multicolumn{5}{c}{ Distance to the apiary } & GLM \\
\cline { 2 - 7 } & $\mathbf{5 0 m}$ & $\mathbf{1 0 0 m}$ & $\mathbf{1 5 0 m}$ & $\mathbf{2 0 0 m}$ & $\mathbf{2 5 0 m}$ & $\operatorname{Pr}>\mathbf{F}$ \\
\hline Density of bees per tree (BPT) & $6.48 \mathrm{a}$ & $6.13 \mathrm{a}$ & $6.2 \mathrm{a}$ & $4.62 \mathrm{~b}$ & $4.05 \mathrm{~b}$ & $<.0001$ \\
Pollination rate (PR) & $53.0 \mathrm{a}$ & $55.8 \mathrm{a}$ & $55.0 \mathrm{a}$ & $52.5 \mathrm{a}$ & $58.3 \mathrm{a}$ & 0.9509 \\
Pollination efficiency (PE) & $9.32 \mathrm{a}$ & $8.04 \mathrm{~b}$ & $6.81 \mathrm{c}$ & $5.95 \mathrm{c}$ & $5.84 \mathrm{c}$ & $<.0001$ \\
Percentage of fruit set initial (PFSi) & $5.15 \mathrm{ab}$ & $5.82 \mathrm{a}$ & $3.55 \mathrm{~b}$ & $4.64 \mathrm{ab}$ & $3.80 \mathrm{~b}$ & 0.0401 \\
Percentage of fruit set final (PFSf) & $0.050 \mathrm{a}$ & $0.045 \mathrm{a}$ & $0.049 \mathrm{a}$ & $0.040 \mathrm{a}$ & $0.030 \mathrm{a}$ & 0.8300 \\
Total number of fruits per tree (NFTT) & $210.7 \mathrm{a}$ & $198.8 \mathrm{a}$ & $192.5 \mathrm{a}$ & $184.5 \mathrm{a}$ & $182.5 \mathrm{a}$ & 0.4871 \\
Weight of fruits per tree (WFTT) & $37.9 \mathrm{a}$ & $33.3 \mathrm{a}$ & $33.7 \mathrm{a}$ & $35.4 \mathrm{a}$ & $34.7 \mathrm{a}$ & 0.6365 \\
\hline
\end{tabular}

* Mean with the same letter in the rows are not significantly different.

\section{Correlation and linear regression between the evaluated variables}

A correlation analysis was performed between the BTP and the evaluated variables. For the variables that were significant, we performed a linear regression analysis. For the variables BPT andPE, ameanpositivecorrelation waspresented (0.50465), when the linear regression was performed $\left(r^{2}=0.2547\right.$, $\left.P<0.0001\right)$. Therefore, only $25 \%$ of the BPT explained only $25 \%$ of PE. For the variables BPT and WFTT, a mean positive correlation was presented (0.50100), when linear regression was performed $\left(r^{2}=\right.$ $0.2510, \mathrm{P}<0.0001)$. Therefore, only $25 \%$ of the BPT explained only $25 \%$ of WFTT.

\section{DISCUSSION}

In Central America, where the avocado is native, it is pollinated by a wide variety of insects, mainly melipona bees and wasps (Ish-Am et al., 1999; Can-Alonso et al., 2005). However, outside of its native region the main pollinator is the honey bee ( $A$. mellifera), whose importance is evident in the strong positive correlation that exists between the activity of the bees and the yield of the crop (Vithanage, 1990; Ish-Am \& Eisikowitch, 1995; Ish-Am \& Eisikowitch, 1998; Gazit \& Degani, 2002). In this study, a mean positive correlation found between honey bee activity and pollination efficiency and total fruit weight per tree emphasizes the dependency of 
avocado pollination and yield on honey bees and the importance of high pollination efficiency for fruit set.

Vithanage (1990) studied the introduction of hives into avocado orchards and found a significant increase in production, on average 227.2 fruits/tree in orchards without hives and 788.2 in orchards with hives, an increase of $247 \%$. Vásquez et al. (2011) used direct pollination with A. mellifera in four varieties of avocado. They incorporated an average of 3.6 hives/ha and found that production increased between $21 \%$ and $96 \%$. These results differed with those found in this research where the average number of fruits/tree was 212 and 231 and the increase in production of 54 and $68 \%$ with the introduction of four and six hives/ha. However, these studies agreed that the activity of honey bees increase the number of fruits. The total weight of the fruits per tree was divided by the total number of fruits per tree, the results were 150 , 180 and 200 grams for the 0, 4 and 6 hives/ ha, respectively. These results indicate that the number of bees per tree had a major effect on the individual fruit weight.

Avocado is characterized as having a low fruit set, and the values worldwide vary from 0.2 to 0.001\% (Salazar \& Lovatt, 1998; Lahav \& Zamet, 1999; Gazit \& Degani, 2002; Cossio-Vargas et al., 2007; Evans, Goodwin, \& Mcbrydie, 2010). The Hass avocado has been described to have a fruit set of $0.14 \%$ in years of high production and $0.07 \%$ in years of low production (Garner \& Lovatt, 2008). Cossio-Vargas et al. (2007) found in Chile in the Hass avocado an initial and final fruit set of $0.04 \%$ and $0.01 \%$. Romero (2012) found in Colombia that the Lorena avocado in a year of high production in of 108,000 flowers, had only 168 fruits.

In this study, it was determined that the $\%$ of fruit set final was 0.05 and $0.04 \%$ when six and four hives/ha were introduced, respectively. These proportions were within the values mentioned for other producing regions. This low fruit set is due to a huge fall of flowers and small fruits during the months following the flowering stage (Lahav \& Zamet, 1999), mostly because of a lack of fertilization (Sedgley, 1987).
Although the avocado flower ovary holds only one ovule, it was demonstrated in the cv. Hass that when only a single pollen grain reaches the stigma the fertilization probability is very low. Actually, twenty pollen grains or more must reach the stigma for a high fertilization probability, so a cooperative effort of many pollen grains is needed for breaking through the style and into the ovary (Ish-Am, 2004; Arpaia \& Hofshi, 2004). In this research, the number of pollen grains in the stigma increased in orchards where four and six hives/ha were introduced, with seven and eight pollen grains in the stigma on average, respectively. However, some collected stigmas contain more than twenty pollen grains per stigma that are necessary to reach a high rate of fertilization (Shoval, 1987).

Ish-Am (2004) reported that five to ten BPT were necessary to achieve a reasonable pollination. However, the optimal density is at least ten to twenty BPT, and six to ten grains of pollen per stigma and 60 to $80 \%$ of pollinated stigmas are obtained. In this investigation with the introduction of four and six hives/ha, six and eight BPT were recorded; based on this assumption a BTP must be present to have a reasonable pollination. However, these data refer to orchards located in Israel, where there are no original native avocado pollinators and few pollinator species and $A$. mellifera is considered the main pollinator. In Colombia, Carabalí et al. (2017) found numerous families of insect pollinators of the avocado, mostly belonging to the orders Diptera, Hymenoptera, Coleoptera and Hemiptera. With this wide diversity of pollinators in Colombia, it is possible that the number of honey bees required is lower than in Israel, as these species contribute to pollination. This information is corroborated by the high pollination rates, greater than $50 \%$, that occurred in all three treatments.

The BPT number was higher in the distance range of 0 to $150 \mathrm{~m}$ which indicates that the distance that exists from the hives to the trees influences the number of bees visiting the flowers of the trees. This coincides with Ish-Am (2004) who determined that the mobility of bees during foraging was limited and worker 
bees operated within an area of one to three trees. At distances between 200 and $250 \mathrm{~m}$, the BPT was smaller, and these bees may have been scouts that had a broader flight range whose objective was to collect information from the available food sources and were able to transport the avocado pollen up to several hundreds meters away from the origin. Based on these results it is recommended to install the hives in the orchard, each spaced at $150 \mathrm{~m}$. This is in agreement with recommendations by Bergh (1977) to place honey bee hives in distant groups up to no more than $160 \mathrm{~m}$.

Honey bee activity was highest in the time period between 11.00 and 14.00 , when the male and female states of the flowers more likely overlapped, the period that the bees move freely between pistillate and staminate flowers and collect pollen and nectar,. These results were similar to those found by Cautin (1996) who determined that the period of the greatest activity of honey bees in avocado orchards was from 11.00 to 14.00 . The results obtained in the orchards affirm that when introducing a different number of hives/ha (six and four) compared to an orchard without hives, there are an increase of bee density per tree, pollination rate, pollination efficiency, $\%$ fruit set initial, \% fruit set final, number of fruits per tree and total fruit weight per tree.

\section{REFERENCES}

Afik, O., Dag, A., Kerem, Z., \& Shafir, S. (2006). Analyses of avocado (Persea americana) nectar properties and their perception by honey bees (Apis mellifera). Journal of Chemical Ecology, 32(9), 1949-1963. https://doi.org/10.1007/s10886-006-9120-1

Afik, O., Delaplane, K.S., Shafir, S., Moo-Valle, H., Quezada-Euán, J.J.G. (2014). Nectar Minerals as regulators of flower visitation in stingless bees and nectar hoarding wasps. Journal of Chemical Ecology, 4a5), 476-483. https://doi.org/10.1007/s10886014-0455-8

Aizen, M.A., \& Harder, L.D. (2009). The Global Stock of Domesticated Honey Bees Is Growing Slower Than Agricultural Demand for Pollination. Current
Biology, 19(11), 915-918, https://doi.org/10.1016/j. cub.2009.03.071

Arpaia, M.L., \& Hofshi, R. (2004). The avocado flower and the pollination process: Ideas from a California perspective. In Proceedings of 2nd Seminario Internacional de Paltos. (p.22) Quillota-Chile.

Avilán, L., \& Rodríguez, M. (1995). Época de floración y cosecha del aguacate en la región norte de Venezuela. Agronomía Tropical, 45, 35-50.

Biesmeijer, J., Roberts, S., Reemer, M., Ohlemüller, R. Edwards, M., Peeters, T., Kunin, W. (2006). Parallel Declines in Pollinators and Insect-Pollinated Plants in Britain and the Netherlands. Science, 5785(313), 351-354. https://doi.org/10.1126/science.1129551

Bergh, B.O. (1977). Factors affecting avocado fruitfulness. In Saults, J. Philips, R y Jackson, L. (eds.) Proceedings of the First International Tropical Fruit Short Course: The Avocado. University of Florida; Gainesville, FL, USA; 83-87.

Brown, M.J., Dicks, L.V., Paxton, R.J., Baldock, K.C., Barron, A.B., Chauzat, M.P., Stout, J.C. (2016). A horizon scans of future threats and opportunities for pollinators and pollination. Peer/ 4, e2249. https://doi. org/10.7717/peerj.2249

Can-Alonzo, C., Quezada-Euán, J., Xiu-Ancona, H., Moo-Valle, H., Valdovinos-Nunez, H., Medina-Peralta, S. (2005). Pollination of "criollo" avocados (Persea americana) and the behavior of associated bees in subtropical Mexico. Journal of Apicultural Research, $44(1), 3-8$.

Carabalí, A., Pinchao, S., Lamprea, I., Peña, J.F., Carabalí, D. (2017). Insectos polinizadores del aguacate (Persea americana Mill.) CV. Hass en Colombia. Bogotá: Corporación Colombiana de Investigación Agropecvaria.

Carvalheiro, L.G., Kunin, W.E., Keil, P., Aguirre, J., Ellis, W.N., Fox, R., Biesmeijer, J.C. (2013). Species richness declines and biotic homogenisation have slowed down for NW-European pollinators and plants. Ecology Letters, 16(7), 870-878. https://doi.org/10.1111/ ele.12121 
Cautin, M. (1996). Nuevos antecedentes sobre requerimientos de polinización y variedades. Publicaciones Misceláneas Agrícolas, 45, 15-29.

Castañeda, A., Equihua, A., Valdés, J., Barrientos, A., Ish-Am, G., Gazit, S. (1999). Insectos polinizadores del Aguacate en los estados de Mexico y Michoacan. Revista Chapingo Serie Horticultura, 5, 129-136. Retrieved from http://bio-nica.info/Biblioteca/Ish-Am polinizadores Aguacate.pdf

Cepeda, J., Gómez, D., \& Nicholls, C. (2014). La estructura importa: abejas visitantes del café y estructura agroecológica principal (EAP) en cafetales. Revista Colombiana de Entomología, 40(2), 241-250.

Cossio-Vargas, L.E., Salazar-Garcia, S., Gonzalez-Duran, I.j., \& Medina-Torres, R. (2007). Algunos aspectos reproductivos del aguacate 'Hass' en clima semicálido. In Proceedings VI World Avocado Congress (Actas VI Congreso Mundial del Aguacate). (p.11) Viña Del Mar-Chile.

Davenport, T.L. (1986). Avocado flowering. Horticultural Reviews, 8, 257-289.

Dewenter, S., Potts, S., \& Packer, L. (2005). Pollinator diversity and crop pollination services are at risk. Trends in Ecology and Evolution, 20, 651-652.

Evans, L.J., Goodwin, R.M., \& Mcbrydie, H.M. (2010). Factors affecting "Hass" avocado (Persea americana) fruit set in New Zealand. Insect Biology, 63, 214-218.

Free, J. (1970). Insect pollination of crops. London: Academic Press.

Free, J., \& Spencer, Y. (1963). The foraging areas of honey bee colonies in fruit orchards. Journal of Horticultural Science, 38, 129-137.

Freitas, B.M., \& Paxton, R.J. (1998). A comparison of two pollinators: the introduced honey bee Apis mellifera and an indigenous bee Centris tarsata on cashew Anacardium occidentale in its native range of NE Brazil. Journal of Applied Ecology, 35, 109-121.
Gallai, N., Salles, J. M., Settele, J., \& Vaissiere, B. E. (2009). Economic valuation of the vulnerability of world agriculture confronted with pollinator decline. Ecological Economics, 68 (3), 810-821.

Garner, L.C., \& Lovatt, C.J. (2008). The Relationship between Flower and Fruit Abscission and Alternate Bearing of 'Hass' Avocado. Journal American Society Horticultural Science, 1, 3-10.

Gazit, S., \& Degani, C. (2002). Reproductive Biology, In The avocado: botany, production and uses (pp. 101-127). Oxon: CABI Publishing.

Geslin, B., Oddie, M., Folschweiller, M., Legras, G., Seymourf, C., Vanveen, C., Thébault, E. (2016). Spatiotemporal changes in flying insect abundance and their functional diversity as a function of distance to natural habitats in a mass flowering crop. Agriculture, Ecosystems and Environment, 229, 21-29. http://dx.doi.org/10.1016/j.agee.2016.05.010 01678809/ã 2016

Goodwin, M. (2012). Pollination of Crops in Australia and New Zealand. Australia: Rural Industries Research and Development Corporation.

Ish-Am, G., \& Eisikowitch, D. (1991a). Possible routes of avocado tree pollination by honey bees. Annals of the Missouri Botanical Garden, 774), 225-233. https://doi.org/10.2307/2399673

Ish-Am, G., \& Eisikowitch, D. (1991b). New insight into avocado flowering in relation to its pollination. California Avocado Society Yearbook, 75, 125-137.

Ish-Am, G., \& Eisikowitch, D. (1993). The behaviour of honey bees (Apis mellifera) visiting avocado (Persea americana) flowers and their contribution to its pollination. Journal of Apicultural Research, 32, 175-186. https://doi.org/10.1080/00218839.1993.11101303

Ish-Am, G., \& Eisikowitch, D. (1995). Quantitative approach to avocado pollination. In Proceedings of The World Avocado Congress III. (pag. 46-51) Israel.

Ish-Am, G., \& Eisikowitch, D. (1998). Low attractive- 


\section{J. APR. SCLI. VOL. 62 NO. 1 2018}

ness of avocado (Persea americana Mill.) flowers to honey bees (Apis mellifera L.) limits fruit set in Israel. Journal of Horticultural Science and Biotechnology, 73(2), 195-204.

Ish-Am, G., Barrientos-Priego, F., Castaneda-Vildozola, A., \& Gazit, S. (1999). Avocado (Persea americana Mill.) pollinators in its region of origin. Revista Chapingo Serie Horticultura, 5, 137-143.

Ish-Am, G., \& Lahav, E. (2011). Evidence for a major role of honey bees (Apis mellifera) rather than wind during avocado (Persea americana Mill.) pollination. Journal of Horticultural Science \& Biotechnology, 86, 589-594. https://doi.org/10.1080/14620316.2011.1 1512808

Ish-Am, G. (2004). Principios de la polinización del palto - Una breve revisión. In Proceedings segundo seminario internacional de paltos. (pag. 11) QuillotaChile.

Klein, A.M., Vaissière, B.E., Cane, J.H., Steffan-Dewenter, I., Cunningham, S.A., Kremen, C., Tscharntke, T. (2007) Importance of pollinators in changing landscapes for world crops. Proceedings of the Royal Society, 274, 303-313.

Lahav, E., \& Zamet, D. (1999). Flowers, fruitlets and fruit drop in avocado trees. Revista Chapingo Serie Horticultura, 5, 95-100.

Malerbo-Souza, D.T., Vagner, T., Rodrigues, S., \& Sousa, F. (2000). Pollination in avocado flowers (Persea americana Mill.). Acta Scientiarum - Agronomy, 2z(4), 937-941.

Mayer, D., Johansen, C., \& Burgett, D. (1986). Bee pollination of tree fruits. USA:Pacific Northwest Extension Publication.

Michener, C. (2000). The bees of the world. Baltimore and London: The Johns Hopkins University Press.

Ne'eman, G., Jürgens, A., Newstrom-Lloyd, L., Potts S.G., Dafni, A. (2010). A framework for comparing pollinator performance: effectiveness and efficien- cy. Biological Reviews, 85, 435-451.

Nieto, A. (1984). Observación preliminar de la polinización entomófila en aguacate Persea americana Mill. Revista Chapingo, 9, 54-55.

Parra, G. (2005). Abejas silvestres y polinización. Manejo Integrado de plagas y agroecología (Costa Rica), 75, 7-20.

Peña, J.E. (2003). Insectos polinizadores de frutales tropicales: no solo las abejas llevan la miel al panal. Manejo Integrado de Plagas y Agroecología (Costa Rica), 69, 6-20.

Pérez-Balam, J., Quezada-Euan, 」., Alfaro-Bates, R., Medina, S., Mckendrick, L., Soro, A., Paxton, R. (2012). The contribution of honey bees, flies and wasps to avocado (Persea americana) pollination in southern Mexico. Journal of Pollination Ecology, 8(6), 42-47.

Potts, S.G., Vulliamy, B., Roberts, S., Toole, C., Dafni, A., Neaposeman, G., Willmer, P. (2005). Role of nesting resources in organizing diverse bee communities in a Mediterranean landscape. Ecological Entomology, 3011), 78-85. https://doi.org/10.1111/j.03076946.2005.00662.x

Romero, M. (2012). Comportamiento fisiológico del aguacate (Persea americana Mill.) Variedad Lorena en la zona de Mariquita, Tolima (Tesis de maestría). Universidad Nacional de Colombia. Bogotá. Colombia.

Salazar, S., \& Lovatt, C. (1998). GA3 application alters flowering phenology of the 'Hass' avocado. Journal of the American Society for Horticultural Science, 123, 791-797.

Sedgley, M. (1987). Foraging Strategy of Honey bee Colonies in a Temperate Deciduous Forest. Ecology, 63(6), 1790-1801. Retrieved from http://www.jstor. org/stable/1940121

Sedgley, M. (1979). Light-microscope study of pollen-tube growth, fertilization and early embryo and endosperm development in the avocado varieties Fuerte and Hass. Annals of Botany, 44, 353-359. 


\section{_ PENA ET HL.___ Pollination and fruit set in avocado by honeybees}

Shoval, S. (1987). Pollination rate and pollen tube growth of avocado, in relation to yield (Master's Thesis). The Hebrew University of Jerusalem. Rehovot. Israel.

Vásquez, R., Ballesteros, H., Tello, J., Castañeda, S., Calvo, N., Ortega, N., Riveros, L. (2011). Polinización dirigida con abejas Apis mellifera: Tecnología para el mejoramiento de la producción de cultivos con potencial exportador. Bogotá: Corporación Colombiana de Investigación Agropecuaria.

Vithanage, V. (1990). The role of the European honey bee (Apis mellifera L.) in avocado pollination. Journal of Horticultural Science and Biotechnology, 65(1), 81-86.

Zych, M., \& Jakubiec, A. (2006). How much is a bee worth? Economic aspects of pollination of selected crops in Poland. Acta Agrobotanica, 59(1), 289-299. 